\title{
PERAN PEKERJA SOSIAL MEDIS SEBAGAI PENDIDIK DALAM PROSES KEMANDIRIAN PASIEN SKIZOFRENIA DI REHABILITASI PSIKOSOSIAL JAKARTA
}

\author{
Novita Sari dan Nurhayati \\ UIN Syarif Hidayatullah Jakarta \\ Email: novitassr05@gmail.com
}

\begin{abstract}
Medical social workers are important in serving patients, specifically in assisting patients in recovery. One of the roles of medical social workers here is as an educator. The role of educators social workers can help people access into information about what is happening in their community, educate the public to build awareness about health problems in their environment, learn about the successes and failures of health efforts, build awareness and habits about healthy lifestyles, and teach ways organizing community activities in health efforts for Schizophrenic patients. The method used in this research is qualitative research. The study subjects consisted of five informants, two Medical Social Workers, and three Schizophrenia patients at the Psychosocial Rehabilitation of Dr. Suharto Heerdjan's Psychiatric Hospital. Data collection is done by observation, interview and documentation. The results of this study: if a schizophrenic patient does many activities to reduce hallucinations, it will have a positive impact on him. In Psychosocial Rehabilitation of Dr. Suharto Heerdjan's Psychiatric Hospital, provided services aimed at making patients independent and reducing recurrence for Schizophrenia patients. Besides that, the patient has skills that are taught as the patient's experience to return to function in the community.
\end{abstract}

Keywords: medical social workers, educators, schizophrenia, independence.

Abstrak. Pekerja sosial medis berperan penting dalam melayani pasien, khususnya dalam mendampingi pasien dalam masa pemulihan. Salah satu peran pekerja sosial medis di sini yaitu sebagai pendidik. Peran pendidik pekerja sosial dapat membantu masyarakat akses pada informasi tentang apa yang terjadi dalam masyarakatnya, mendidik masyarakat untuk membangun kesadaran tentang masalah-masalah kesehatan di lingkungannya, mempelajari kesuksesan dan kegagalan dari usaha kesehatan, membangun kesadaran dan kebiasaan tentang pola hidup sehat, serta mengajarkan cara mengorganisasikan keggiatan masyarakat dalam usaha kesehatan bagi pasien Skizofrenina. Metode yang digunakan pada penelitian ini adalah penelitian kualitatif. Subyekpenelitian terdiridarilima informan, dua Pekerja Sosial Medis, dan tiga pasien Skizofrenia di Rehabilitasi Psikososial Rumah Sakit Jiwa Dr. Soeharto Heerdjan. Pengumpulan data dilakukan dengan observasi, wawancara dan dokumentasi. Hasil dari penelitian ini: jika pasien skizofrenia melakukan banyak kegiatan untuk mengurangi berhalusinasi, hal itu memberi dampak positif bagi dirinya. Di Rehabilitasi Psikososial Rumah Sakit Jiwa Dr. Soeharto Heerdjan, diberikan pelayanan yang bertujuan membuat pasien mandiri dan mengurangi kekambuhan bagi pasien Skizofrenia. Selain itu membuat pasien memiliki keterampilan yang diajarkan sebagai pengalaman pasien untuk kembali berfungsi di lingkungan masyarakat.

Kata Kunci: pekerja sosial medis, pendidik, skizofrenia, kemandirian. 


\section{Peran Pekerja Sosial Medis sebagai Pendidik dalam Proses Kemandirian Pasien \\ Skizofrenia di Rehabilitasi Psikososial Jakarta}

- Novita Sari dan Nurhayati

\section{Pendahuluan}

Peran pendidik berupa pengajaran yang artinya, para pekerja sosial (peksos) medis, dalam settingan agenda pengajaran, dapat memimpin kelompok dalam sebuah edukasi seperti mengajarkan klien bagaimana mencari informasi dan berkonsultasi dengan profesi kesehatan terkait dengan obat yang klien gunakan, mengajarkan klien bagaimana cara berintegrasi kembali di masyarakat, memberikan pengetahuan terhadap klien dan masyarakat tentang stigma sosial, dan mengajarkan keterampilan kepada klien. Ini adalah salah satu bagian dari intervensi terhadap para klien.

Salah satu bentuk peran pekerja sosial medis sebagai pendidik adalah pengajaran dengan menggunakan teori Roberts dan Greene (2009) yang dapat dilihat bagaimana pekerja sosial sebagai pendidik memainkan peran sehingga menghasilkan praktik intervensi pengajaran dalam ranah pekerja sosial yang lebih efektif. Suatu metode terstruktur yang mengajarkan secara langsung berupa pelatihan keterampilan sosial bagi pasien skizofrenia.

Peran pendidik pekerja sosial dapat membantu masyarakat akses pada informasi tentang apa yang terjadi dalam masyarakatnya, mendidik masyarakat untuk membangun kesadaran tentang masalah-masalah kesehatan di lingkungannya, mempelajari kesuksesan dan kegagalan dari usaha kesehatan, membangun kesadaran dan kebiasaan tentang pola hidup sehat, serta mengajarkan cara mengorganisasikan kegiatan masyarakat dalam usaha kesehatan bagi pasien skizofrenia.

Skizofrenia merupakan gangguan jiwa yang terjadi akibat serangan beberapa faktor seperti perubahan fisik dan kimia pada otak, serta genetik yang mempengaruhi fungsi individu dalam berpikir, menerima, merasakan, dan berperilaku menjadi tidak dapat diterima secara sosial. Banyaknya pasien skizofrenia memicu adanya masalah sosial.

Pekerja sosial adalah seseorang yang memiliki kewenangan dan keahlian dalam menyelenggarakan berbagai pelayanan sosial. Pekerja sosial sebagai salah satu profesi yang berfokus pada keberfungsian sosial klien dan interaksi lingkungan sosial klien sejatinya memiliki peran yang sangat penting dalam hal pemulihan sosial bagi pasien skizofrenia. Dengan menggunakan pemahaman sistem dasar pekerja sosial, akan terlihat bagaimana lingkungan dapat menjadi satu faktor yang sangat penting bagi proses penyembuhan. Oleh karena itu, untuk membantu pemulihan bagi penyandang skizofrenia di rumah sakit 
diperlukan tenaga pekerja sosial profesional atau pendamping sosial yang kompeten (terstandar) yaitu Pekerja Sosial Medis.

Pasien skizofrenia sebagai sosok pribadi yang utuh memiliki hak-hak dasar yang harus diperjuangkan. Gangguan kejiwaan tentunya tidak mempengaruhi lingkungan untuk dapat mengakomodir hak asasi manusia yang dimiliki oleh Pasien Skizofrenia.

Berdasarkan pemaparan di atas, penulis tertarik untuk melakukan pemabahasan lebih lanjut mengenai. "Peran Pekerja Sosial Medis sebagai Pendidik dalam proses Kemandirian Pasien Skizofrenia di Rehbilitasi Psikososial RSJ Dr.Soeharto Heerdjan Jakarta."

\section{Metode}

Penelitian ini menggunakan pendekatan kualitatif dengan metode studi kasus dengan pertimbangan bahwa metode studi kasus sesuai dengan jenis penelitian dan subyek yang diteliti. Penelitian kualitatif menghasilkan data deskriptif yakni berupa kata-kata tertulis atau lisan dari orang-orang dan atau bersumber dari perilaku yang dapat diamati (Bogdan dan Taylor dalam Moleong, 2007). Sedangkan studi kasus digunakan sebagai suatu penyelidikan empirik terhadap fenomena dalam kehidupan nyata yang berguna untuk menghadirkan penjelasan yang komprehensif terkait berbagai aspek dari seseorang, kelompok, organisasi, program, atau situasi kemasyarakatan (Yin, 1996). Studi kasus merupakan upaya penyelidikan yang mendalam.

Beberapa teoris menyebut bahwa pendekatan kualitatif bisa juga disebut sebagai case study, sebab pendekatan kualitatif merupakan penelitian yang mendalam dan detail terhadap segala sesuatu yang memiliki hubungan dengan subyek penelitian (Lincoln dan Guba dalam Pujosuwarno, 1992).

Berdasarkan tujuan dari penelitian ini yaitu untuk mengetahui peran dari pekerja sosial medis sebagai pendidik dalam layanan rehabilitasi psikososial. Penelitian ini dikategorikan sebagai penelitian deskriptif. Penelitian ini dimaksudkan untuk dapat mengetahui peran-peran pekerja sosial sebagai pendidik pada pelayanan rehabilitasi psikososial di Rumah Sakit Jiwa Dr. Soeharto Heerdjan yang membantu proses alumni dari rehabilitasi psikososial untuk bisa kembali ke masyarakat. Untuk mendapatkan informasi atau data diri dari informan, peneliti melakukan tatap muka secara langsung dengan informan.

Agar informasi dapat tergali dengan baik, maka informan yang dipilih 


\section{Peran Pekerja Sosial Medis sebagai Pendidik dalam Proses Kemandirian Pasien Skizofrenia di Rehabilitasi Psikososial Jakarta}

- Novita Sari dan Nurhayati

dalam penelitian ini adalah informan yang mengetahui situasi serta kondisi masalah penelitian. Informan yang dipilih yakni informan yang terlibat langsung maupun tidak langsung yang berkaitan dengan pekerja sosial sebagai pendidik di bagian rehabilitasi psikososial di Rumah Sakit Jiwa Dr. Soeharto Heerdjan. Kriteria informan yang dipilih peneliti dilakukan guna mendapatkan informasi yang sesuai dengan tema penelitian. Dalam penelitian ini peneliti memiliki dua macam informan, dua pekerja sosial medis sebagai informan utama, dan tiga pasien yang terdiagnosa skizofrenia di Rehabilitasi Rumah Sakit Jiwa Dr. Soeharto Heerdjan. Pemilihan pasien ditentukan berdasarkan kriteria tingkat dari kemandirian yang dibedakan secara jangka waktu pasien berada di Rehabilitasi Psikososial Rumah Sakit Jiwa Dr. Soeharto Heerdjan.

Penelitian ini menggunakan teknik pengumpulan data berupa: a. Data primer: 1) wawancara, wawancara yakni sebuah metode yang digunakan untuuk memperoleh data atau keterangan secara lisan dari informan melalui sebuah proses percakapan yang sistematis serta terperinci. Dalam pelaksanaan wawancara, digunakan sebuah pedoman wawancara dengan tujuan pedoman ini memiliki fungsi sebagai aspek yang akan dibahas berasama informan; 2) Observasi Non-Partisipatif. b. Data sekunder: 1) Studi Dokumentasi dan 2) Studi Kepustakaan

Studi dokumentasi yakni berkaitan dengan artikel, jurnal, buku, yang berkaitan dengan rehabilitasi psikososial di Rumah Sakit Jiwa Dr. Soeharto Heerdjan. Studi Kepustakaan digunakan sebagai bahan pertimbangan untuk informasi tambahan dan alat perbandingan.

Adapun instrumen pengumpulan data yang digunakan dalam penelitian ini yakni sebagai berikut: a. Wawancara, pedoman wawancara digunakan untuk membantu peneliti dalam memperoleh data yang sistematis dan terstruktur dalam proses penggalian informasi terkait peran pekerja sosial medis sebagai pendidik di rehabilitasi psikososial bagi pasien gangguan jiwa di rumah sakit Jiwa Dr. Soeharto Heerdjan. b. Observasi, pedoman observasi digunakan dengan tujuan agar dapat menghasilkan sebuah catatan lapangan mengenai kejadian yang di observasi oleh peneliti selama melakukan pengamatan terkait pelayan rehabilitasi psikososial di rumah sakit jiwa Dr. Soeharto Heerdjan. c. Alat Bantu, alat bantu yang digunakan dalam proses penelitian ini yakni berupa perekam suara dan kamera untuk mendokumentasikan hal yang dianggap penting dan dibutuhkan untuk menunjang data penelitian. Selain itu, alat bantu perekam 
suara digunakan sebagai alat bantu pengingat bagi peneliti dalam proses penggalian informasi melalui wawancara.

Untuk memastikan keabsahan data ini, peneliti menggunakan triangulasi data. Untuk memanfaatkan sesuatu yang lain di luar data itu untuk keperluan pengecekan atau pembanding terhadap data itu. Triangulasi digunakan lebih dari satu orang dalam pengumpulan dan analisi data dalam berbagai cara yang dilakukan untuk ke validan data.

\section{Hasil dan Diskusi}

Permasalahan skizofrenia membuat Kementrian Kesehatan mendirikan banyak fasilitas untuk menekan angka pasien tersebut. Rumah Sakit Jiwa Dr. Soeharto Heerdjan merupakan salah satu rumah sakit jiwa yang berada di bawah Kementrian Kesehatan. Rumah sakit jiwa ini terletak di Grogol, Jakarta Barat. Rumah sakit jiwa ini menjalankan banyak layanan untuk memfasilitasi pasien skizofrenia. Dari sekian layanan yang diberikan oleh rumah sakit jiwa tersebut, ada satu layanan unggulan yaitu layanan rehabilitasi psikososial.

Di instalasi rehabilitasi psikososial RSJ Dr. Soeharto Heerdjan ini mengajarkan dan melatih kemandirian pasien skizofrenia agar nantinya dapat re-integrasi ke masyarakat. Di dalam rehabilitasi psikososial ada profesi pekerja sosial medis yang mengajarkan pasien skizofrenia untuk mendapatkan kegiatankegiatan yang ada di pelayanan dan dapat diberikan pelatihan agar saat kembali ke masyarakat, pasien skizofrenia akan memiliki suatu keahlian seperti bisa mandiri dalam merawat dirinya sendiri (mandi, merapihkan rumah, makan, berpakaian, berpindah tempat, dan ke toilet sendiri) keterampilan dalam seni tari, seni musik, spiritual, menjahit, bertataboga, berwirausaha, salon, kerajinan tangan, berkebun, dan mengikuti kelas khusus seperi kelas bahasa inggris, administrasi, komputer, dan remedial.

Peran pekerja sosial medis dalam hal ini sangat diperlukan mengingat pentingnya program yang diterapkan di Instalasi Rehabilitasi Psikososial tersebut. Seorang pekerja sosial medis dapat bermain dalam perannya mengingat kompetensi dan fungsi yang dimiliki. Pekerja sosial medis dalam pendampingannya dapat memaksimalkan fungsi dari program yang diberlakukan dengan perannya sebagai pendidik.

Pasien skizofrenia berhak mendapatkan pelayanan kesehatan untuk kesembuhannya. Untuk memperoleh kesembuhannya pasien skizofrenia harus 


\section{Peran Pekerja Sosial Medis sebagai Pendidik dalam Proses Kemandirian Pasien \\ Skizofrenia di Rehabilitasi Psikososial Jakarta}

- Novita Sari dan Nurhayati

melewati berbagai macam terapi, salah satunya adalah terapi perilaku. Salah satu fungsi dari terapi perilaku yang dijalankan pasien skizofrenia terdapat pelatihan kemandirian melalui kegiatan-kegiatan yang ada di Pelayanan sosial. Untuk mengetahui peningkatan kemandirian pasien skizofrenia dalam kemandiriannya, suatu institusi memberlakukan peran. Pekerja sosial medis sebagai pihak yang memiliki kompetensi sebagai Perannya.

Fungsi pekerja sosial yang telah dipaparkan di atas dapat memenuhi fungsi dari pendampingan yang diharapkan oleh suatu institusi. Selain itu, fungsi pekerja sosial tersebut dapat membantu pekerja sosial untuk dekat dengan pasien skizofrenia serta membantunya untuk melewati kegiatan terapi yang telah disiapkan oleh institusi.

Hasil dari penelitian ini menegaskan bahwa pasien skizofrenia akan berdampak positif jika melakukan banyak kegiatan untuk mengurangi berhalusinasi. Di Rehabilitasi Psikosoial Rumah Jiwa Soeharto Heerdjan memberikan pelayanan yang bertujuan membuat pasien mandiri dan mengurangi kekambuhan bagi pasien Skizofrenia, selain itu membuat pasien memiliki skill/keterampilan yang diajarkan di dalam Rehabilitasi Psikososial, Skill tersebut berguna sebagai pengalaman pasien untuk mengembalikan keberfungsian sosialnya di dalam lingkungan masyarakat. Terutama pasien bisa stabil dalam emosinya jika bertemu dengan banyak orang dan bersosialisasi dengan baik dengan banyak orang. Seperti pasien siap untuk bekerja dari skill yang diajarkan di Rehabilitasi Psikososial, bisa membuka usaha sendiri, dan bisa melanjutkan sekolah dengan keadaan emosi pasien yang sudah stabil dan tidak mudah kambuh.

\section{Kesimpulan}

Berdasarkan pembahasan dalam penelitian ini, penulis menyimpulkan bahwa Peran pekerja sosial medis sebagai pendidik merupakan suatu bentuk pelayanan dalam mendampingi pasien untuk mendapatkan hak-haknya. Hal ini dilihat dari proses peranan yang diberikan oleh pekerja sosial medis di rehabilitasi Rumah Sakit Jiwa Dr. Soeharto Heerdjan. Peran pendidik di sini merupakan pekerja sosial yang dapat membantu masyarakat pada akses informasi tentang apa yang terjadi dalam masyarakatnya, mendidik masyarakat untuk membangun kesadaran tentang masalah-masalah kesehatan di lingkungannya, mempelajari kesuksesan dan kegagalan dari usaha 
kesehatan, membangun kesadaran dan kebiasaan tentang pola hidup sehat, serta mengajarkan cara mengorganisasikan kegiatan masyarakat dalam usaha kesehatan bagi pasien skizofrenia dalam proses kemandirian pasien.

\section{Daftar Pustaka}

Creswell, J.W. (2010). Research Design Pendekatan Kualitatif, Kuantitatif, dan Mixed. Yogyakarta : Pustaka Pelajar

Moleong, L.J. (2007). Metodologi Penelitian Kualitatif. Bandung: Penerbit PT Remaja Rosdakarya.

Pujosuwarno, S. (1992). Petunjuk Praktis Pelaksanaan Konseling. Yogyakarta: Menara Mas Offset.

Roberts R.A., \& Greene J.G. (2002). Buku Pintar Pekerja Sosial. Jakarta: PT BPK Gunung Mulia

Yin, R.K. (1996). Studi Kasus: Desain dan Metode. Jakarta: PT. Raja Grafindo Persada.

Rachmaningtyas, A. (2013, 24 April). Kemensos: Solusi bagi penderita sakit jiwa rehabilitas sosial. SindoNews.com. Diakses dari https://nasional. sindonews.com/read/741550/15/kemensos-solusi-bagi-penderitasakit-jiwa-rehabilitasi-sosial-1366796112

Data RSJ Dr. Soeharto Heerdjan. Diakses dari dari https://rsjsh.co.id/ 